\title{
Anmeldelse af Dansk Sproghistorie 4. Dansk i brug
}

Udgivet af Det Danske Sprog- og Litteraturselskab, hovedredaktør Ebba Hjorth, Aarhus Universitetsforlag, 2020, 416 sider.

\section{OLE TOGEBY}

Det første man kan sige om dette bind 4 af Dansk Sproghistorie, er at det er flot, rigt illustreret, indbundet, i stort kvadratisk format og meget vægtig; det vejer 1,8 kg, så man ganske simpelt ikke kan sidde i en lænestol og læse det, for man kan ikke holde det oppe. Et bind af Skautrups Det danske Sprogs Historie vejer kun halvdelen. Det havde været behageligere med otte lidt lettere bind end seks så tunge.

Bind 4 (af 6) af Dansk Sproghistorie hedder Dansk i brug. Dette bind er ikke decideret om sprogets historie, men snarere kapitler til en stilog genre- og skolehistorie. Bindet indeholder 16 afsnit skrevet af hver sin forfatter, fordelt på fire kapitler, nemlig 14. Lov, bibel og salmer, 15. Viser, sange og ordsprog, 16. Sprog og medier og 17. Dannelse og uddannelse. Disse fire kapitler og 16 afsnit skal her refereres og karakteriseres hver for sig.

\section{LOV, BIBEL OG SALMER}

Det første afsnit i det første kapitel hedder Juridisk sprog før 1700 (29 sider) og er skrevet af Britta Olrik Frederiksen. Det handler om landskabslove og de diplomer som fra omkring 1400-tallet bliver forfattet på dansk. Det særlige ved landskabslovene og til en vis grad Christian 5.s Danske lov er at de er kasuistiske, og ikke almene. Det vil sige at de består af et retstilfælde, fx Drapar man køuen racka ('dræber en mand en skødehund'), og en sædvaneretslig resolution, Bøte siax øre ('skal han bøde seks øre’). Der står altså ikke som i de gammeltestamentlige 10 bud hvad man skal eller ikke må, eller hvem der påbyder det: Du må ikke begå drab, men kun: den der gør det, skal efter sædvanen have en straf. Denne stil i danske love kan forøvrigt spores op til den dag i dag, 
hvor danske love stadig formuleres anderledes end EU-lovene som er skrevet i traditionen efter romerretten.

I kapitlet beskrives lovteksternes historie, og det forklares at formuleringerne bærer præg af at være nedskrivninger af germanske mundtlige sædvaneregler med mange upersonlige, mundtlige og mere litterære træk som rim, rytme, alliteration, gentagelser, modstillinger, replikker, sentenser og billedsprog. Det står i modsætning til de romerske kanoniske love som er mere abstrakte og med synlig lovgiver. Kapitlet giver således en beskrivelse af hvorledes lovsproget var, og giver en god forklaring på hvorfor stilen blev som den blev.

Det man kunne savne, er en beskrivelse af hvilken virkning dette sprogligt-stilistiske særpræg så havde. Var retstilstanden i de nordgermanske lande anderledes end i de romanske lande, hvor romerretten har dannet det stilistiske forbillede. Altså ikke blot: således former samfundet og historien sproget, men også: således former sproget samfundet og historien.

Afsnit 14.2 Juridisk sprog efter 1700 (18 sider) af Per Andersen lægger også ud med de forskellige retsfamilier: en germansk, en romanistisk, en nordisk og en engelsk som er grundlaget for forvaltning i enevælden, og Andersen karakteriserer den juridiske stil ved forvægt, verbalsubstantiver, kancellisløjfer, gammeldags ord, passive verbaler, og hele sagen i en helsætning (et træk som stadig findes i patentbeskrivelser). Denne stil ændres senere ved at man går fra kancellisprog til klarsprog. Retspositivisme beskrives ved at jura er hvad ret er, mens moral er hvad ret burde være. Det at velfærd og social lighed er blevet vigtigere end frihedsrettighederne får Per Andersen til at spørge om retsstat og demokrati er uforenelige. Men han svarer ikke på det.

Afsnit 14.3 Bibelsprog (40 sider) er skrevet af Bodil Ejrnæs. Bibeloversættelserne er et udmærket valg til undersøgelse af stilistiske variationer, for man må jo gå ud fra at indholdet i en eller anden forstand skal være det samme. Variationen beskrives detaljeret og overbevisende i tre faser:

1. fase (1500-1600) med Lutheroversættelserne, hvorfra vi har mundret sprog og ord og formuleringer, såsom: nidkarhed, pagt, naste, ark, syndflod, helligt vorde dit navn, liggende fa, ikke en tøddel, kaste perler for svin, gråd og tonders gnidsel. 2. fase (1600-1900) med de Re- 
sen-Svanningske Bibler der har tungt, knudret og vanskeligt sprog og ord (med angivelse af hvad de siden er erstattet med): kundskabens tra, omvendelse, opbyggelse, udstrakt fastning (> hvalving), gjorde skilsmisse (> satte skel); asen (> asel); tabernaklet (> boligen); boler (> elsker); sad (> afkom). 3. fase (1931 og 1992 og den ikke-autoriserede Den nye aftale 2007 (Bibelen 2020 nåede ikke at komme med)): ord der er forsvundet i 1992: misdader (> forbryder), miskundhed (> godhed), i uforkrankelighed (> i uforgangelighed, og i Bibelen $2020>$ udødeligt), nidkar (> lidenskabelig), genløser, bie, tvatte, blusel (> kønsdele), kalk (> bager), stimand, trette, frugtsommelig.

Med dette meget velegnede materiale kunne man let have overvejet de fundamentale sprogvidenskabelige problemer om to formuleringer semantisk set er synonyme og 'betyder det samme', og hvorfor ord forsvinder ud af brug. Det er klart nok at vi skaber nye ord når vi har brug for dem, men hvorfor er der ord vi ikke har brug for længere? Man kunne $\mathrm{fx}$ have undersøgt hvorfor ordet miskundhed, fx i Salmernes bog Til himlene rakker din miskundhed, Gud, ikke kan bruges mere, men er erstattet af nåde, barmhjertighed og nu godhed. Er det fordi miskundhed oprindeligt betød 'nåde', og dette begreb ikke længere henviser til noget? Det havde været godt med lidt idéhistoriske overvejelser.

14.4 Salmesprog (17 sider) af Marita Akhøj Nielsen beskriver hvordan danske samler vinder frem efter reformationen, og at deres sprog er præget af at teksterne har metrisk form og skal være sangbare. Men kapitlet er lidt amputeret fordi Kingo med det tætte billedsprog og Grundtvig med det nordiske ordforråd kun nævnes i forbigående eftersom der skal komme hele afsnit om de to forfattere i bind 6, Forfatternes dansk. Vi får dog til sidst citeret et par strofer af Simon Grotrian med det sproglige billede Jomfrukarten slukker Midgårdsormen, som Marita Akhøj Nielsen karakteriserer som paradoksalt med både kristne og hedenske forestillinger så det næppe kan tolkes entydigt.

Kapitel 14. Lov, bibel og salmer er således solid og traditionel stil- og genrehistorie som det er beskrevet før.

\section{VISER SANGE OG ORDSPROG}

15.1. Folkeviser (29 sider) af Dorthe Duncker orienterer om håndskrifterne og de to hovedsamlinger: Svend Grundtvigs Danmarks gamle Fol- 
keviser og Hakon Grüner-Nielsens Danske Viser fra Adelsvisebøger og om undergenrerne ballader, lyriske viser og andre viser. Af sproglige træk fremhæves bogstavrim, inversion, ekspletiv refleksiv, fx rider sig under $\emptyset$, forældede bøjningsformer, $\mathrm{fx}$ på kviste, til senge, røden guld, sorten muld, foransat bestemt artikel, $\mathrm{fx}$ den svend. Der fremsættes (i en billedtekst) følgende tese: "Dette tyder på at genretypiske træk opformeres i viserne i løbet af indsamlingsperioden" (side 128). Man må forstå det således at antallet af nævnte træk gennem tiden stiger fra tidlige lyriske viser, over historiske viser, episke viser, romanviser, (endnu engang) historiske viser, kæmpeviser, ridderviser, trylleviser og til sene lyriske viser. Med andre ord, stilen i folkeviserne er ikke arkaisk, men arkaistisk, dvs. tilstræbt arkaisk.

Af andre sproglige træk nævnes stereotype gentagelser og faste forbindelser, fx skønne jomfru, liden smådreng, den vane mår, korte helsætninger, få ledsætninger, omvendt ordstilling: moder min, vilje sin (som er sat ind af metriske hensyn), ekstraposition før fundamentfeltet messen hun var sungen, fremrykkede objekter, $\mathrm{fx}$ din hest kan du ikke ride, han sit svard drog ud, indholdsadverbialer på pladsen for neksusadverbialer: Hun tog over sig skarlagenskind, Han ind ad døren tren, lyrisk sig. Jeg var mig en fattig ungersvend, imperativ + pronomen: Tag $d u$ nu den store sten, og den såkaldte balladeske sætningskløvning: Det var here Tidemand, slar ofver hinde skarlagen-skind. Det kaldes balladesk fordi det ikke er en ægte sætningskløvning hvor den efterstillede sætning nemlig er præsupponeret, og der laves kontrast.

Balladernes sprog er således beskrevet meget omhyggeligt og sat i relation til de forskellige visers alder, men man kunne savne en diskussion mellem disse sproglige overvejelser over kronologien og så de litterære overvejelser over motivernes udvikling fra dæmoni til psykologi; Svend Grundtvigs inddeling giver til sammenligning rækkfølgen: kæmpeviser, trylleviser historiske viser, ridderviser, romanviser.

15.2 Højskolesangen (14 sider) af Nanna Damsholt, fremhæver for alle 18 udgaver af Højskolesangbogen de enkle melodier, "det var aldrig den æstetiske kvalitet af sangen der talte, men at alle sang med, hver med sit næb” (side 152). I de første udgaver var der modstand mod tysk indflydelse, fx med Lange nok har jeg bondepige varet (1850), fremhævelse af sprogets styrke, $\mathrm{fx}$ i Den danske sang er en ung blond pige, 
brug af bolle- $a$ lige fra begyndelsen, og i senere udgaver kommer der arbejdersange, besættelsens sange og Benny Andersens sange. Det der i dette afsnit står om sprogets historie, er at man gennem fællessang kan synge sig ind i det danske sprog. "Det VAR DE DANSKe SKJALDE DeR SANG" er blevet erstattet af "SÅ SYNG DA DANMARK, LAD hJERTET TALE" (side 150).

15.3. Lejlighedsdigte og festsange (16 sider) er skrevet af Ebbe Preisler. Festsange defineres her som sange skrevet på kendte melodier, til festlige lejligheder og af personer med personlig tilknytning til festens genstand, og de hævdes ikke at eksistere i andre sprogområder. De dominerende sproglige træk i lejlighedssange er omvendt ordstilling og rim, og at versene er, som Preisler skriver, vitaminfattige og ubehjælpsomme.

Det fremhæves i afsnittet at et særtræk ved festsangen er at de mangfoldiggjorte tekster bæres frem i sangskjulere som forestiller noget med relation til festens genstand, fx en model af fødselarens båd, og synges af de tilstedeværende gæster.

En nærliggende genre er vandresangen, fx Højt på en gren en krage sad, og købesangen som næppe kan blive så personlig som den ægte festsang. Bording, Kingo, og Grundtvigs har alle skrevet lejlighedssange, som så senere er blevet offentliggjort som digte, fx Det er så yndigt at folges ad og Wessels: At Smørrebrød er ikke Mad,log Kierlighed er ikke Had,/det er for Tiden hvad jeg veedlom Smørrebrød og Kicrlighed.

15.4. Ordsprog og talemåder (12 sider) af Merete Korvenius Jørgensen. Ordsprogenes historie er i store træk: Peder Låle 1450, Daniel Matras 1633 og Peder Syv 1682. Nabogenrer til ordsprog beskriver Merete Korvenius Jørgensen som aforismer, bevingede ord, fyndord, maksimer, mundheld, regler, talemåder, og wellerismer som alle defineres kort og præcist. Ordsprog er sprogligt karakteristiske ved konsistens i den ydre form, enkel syntaks, artikelløse substantiver, fx Nød bryder ret. Tvetydigheden i Det er ikke alt guld, som glimrer bemærkes (enten 'noget guld glimrer ikke', eller 'noget glimmer er ikke guld'), men der gives ingen syntaktiske eller semantiske forklaringer på hvordan det kan ske.

Kapitel 15 er beskrivelse af fire forskellige tekstarters særpræg og historie, men de sættes ikke i forhold til hinanden, og sproget bliver i et par af dem næsten ikke systematisk beskrevet. 


\section{SPROG OG MEDIER}

16.1 Aviser, radio og tv (37 sider) er skrevet af Ib Poulsen. Her skelnes der med prisværdigt teoretisk overblik mellem fire niveauer i beskrivelsen: medier, genre, retorik samt sprog og stil, og vekselvirkningen mellem de fire niveauer beskrives på udmærket vis med tre nedslag $\mathrm{i}$ udviklingen af Berlingske som illustrativt eksempel.

I Danmark begynder mediernes historie i 1749 med det der nu hedder Berlingske som er en trykt avis karakteriseret af korte nyheder, stor sætningslængde, tysk ordstilling, forvægt, mange fremmedord og mange titler. I 1849 har Berlingskes artikler fåt komposition med spændingskurve, pointe, citater, ræsonnerende stil og rubrikker, og i 1945 er avisen fuld af beskrivelser og omskrevne udtalelser af offentlige personer, engelske ord, paratakse, få ledsætninger og en direkte og kritisk tone.

Historisk set opstår der forskellige medieundertyper som stifttidender, provinspresse, partipresse, løssalgsaviser (med holdningstilkendegivende ledere og mundtlighed), Illustreret Familie Journal og magasinpresse. Fra 1900 adskiller Cavling nyhed og debat og indfører interviews, skriften bliver antikva, og ud over nyheder (som nu komponeres efter nyhedstrekanten) kommer der emner som sport, trafik, kriminalitet, ulykker, kvinde- og familiestof.

Særlig fræk er Ekstra Bladet der "tør hvor andre tier", og vi får fænomener som New Journalism med scenisk fremstilling, dialog, synsvinkel og symbolik, og som Gonzo-journalistik hvor reporteren (Morten Sabroe) er i centrum. I dag har vi så netaviser, som kan læses multimodalt og på flere niveauer, og hvor distance i tid og rum afløses af samtidighed og inklusion.

I det nye medie radio erstattes efterhånden oplæst skrift på rigsdansk i upersonlig stil med personlig henvendelse i talesprog. TV går fra at være radio med billeder til udsendelsestyper med dramaturgi, synlige studieværter, fatisk kommunikation, deiktiske pronominer, dialogpartikler og genoptaget fundament.

16.2. E-mail, sms, chat og sociale medier (13 sider) er skrevet af Ditte Laursen og Marianne Rathje. De definerer elektronisk kommunikation som fjernkommunikeret skrift der er næsten simultan. De tekniske muligheder og begrænsninger skaber nye genrer og forårsager forandringer i sproget. 
Først var der den alvorlige hindring at en SMS skulle tastes på en mobiltelefon med 4-3 bogstaver på hver tast, siden har vi fået hele tastaturer, og det har lettet indtastningen, men der forekommer stadig mange formelle fejl, $\mathrm{fx}$ undlader man at bruge store bogstaver. Da der ikke er tid til redigering, sker der mange reduktioner, som i gammeldags telegramstil. Der udelades tegn og bruges forkortelser, evt. forskellige forkortelser af samme ord: godnat kan forkortes gonat, gnat, nat, gn. Disse træk er ved at forsvinde igen efter at der nu ikke kun, som før, er 160 tegn i en meddelelse. De intelligente ordbøger kan give sjove resultater og kontaminationer er hyppige.

Chat der foregår via en computer, og statusopdateringer på sociale medier (fx Facebook) giver nye muligheder for responser som likes og kommentarer, og manglende respons er blevet en potentiel trussel mod relationen mellem fjerne men simultane partnere. I gruppefora opstår der gruppesprog der fungerer som shiboletter der lukker folk ude.

Det at der ikke i den næsten simultane interaktion er nogen mulighed for mimik, fremkalder træk som lydefterligning, interjektioner, smileys, emojis og generelle udvidere, fx eller wa? Mange har deres personlig stil med disse tegn. Der synes dog ikke - skriver forfatterne - af den grund at ske et sproglig forarmning, for de unge kan skelne mellem genrerne; der er således ikke mange elektroniske sprogtræk i danske stile. I dette afsnit er der således på udmærket vis gjort rede for elektronikkens påvirkning af sproget og sprogets påvirkning af samfundet.

Kapitel 16 Sprog og medier er det mest vellykkede kapitel i dette bind, med overvejelser over påvirkningsvejene mellem tekniske muligheder, tekstarterne i samfundets institutioner og stil og variationer i sprogbrugen.

\section{DANNELSE OG UDDANNELSE}

17.1 Lase- og skrivekyndighed for 1800 (24 sider) er skrevet af Charlotte Appel, som indledningsvis konstaterer at runerne var i brug i 1300 år (mens det latinske alfabet har været i brug i Danmark i 1000 år). Runeindskrifter fra Bergen har vist at runer især blev ristet på træ med en kniv til almindelige formål som huskesedler og kærestebreve, og at indskrifter på sten har været en sjældenhed. Kyndigheden i brugen af runer har dog måske været noget andet end i brugen af bogstaver, for 
- som Charlotte Appel skriver - runer ristes og rådes, mens bogstaver skrives og lases.

Latinsk tekst skrevet med latinske bogstaver bidrog i høj grad til sikring af magten ved at dokumentere rettigheder og besiddelser, og mængden af dokumenter steg fra 23 dokumenter i perioden 1100 1125 til 3.937 i 1375-1400, og mængden øges yderligere da papir bliver almindeligt. Den første bogtrykker kom til Danmark i 1482, og de første tryk var Luthers lille katekismus, kirkebøger, ABC’er, og folkebøger. Man antager at $1 / 3$ af alle mænd i byerne kunne skrive på dette tidspunkt, 1/10 på landet. Fra 1800 kunne de fleste læse, dog læste de mest religiøse tekster, og først i 1814 indføres ved lov undervisning af alle børn i både læsning og skrivning.

17.2 Lase-og skrivekyndighed efter 1800 (33 sider) er skrevet af Vibeke Sandersen om hvorledes færdighederne i at læse og skrive blev udbredt til hele landet i løbet af to hundrede år. Den undervisning der indførtes 1814 , var ikke klasseundervisning, men var organiseret indbyrdes undervisning, hvor de ældre elever underviste de yngre ved hjælp af læse- og regnetavler. Bibliotekerne voksede frem med 10 i 1800 og i $2 / 3$ af landes sogne i 1889. Læseforeninger, højskoler, og kolportage af læsestof udbredte gennem århundredet læsefærdigheden over hele landet. Læsestoffet var aviser, ugeblade, og litteratur, fx Gøngehøvdingen.

Der blev undervist (ordnet efter faldende vægt) i skønskrift, retskrivning, tegnsætning og indhold. Skrivefærdigheden er dokumenteret blandt tugthusfanger på Møn til $21 \%$ i 1818, og 58 \% i 1850. I soldaterbreve 1848-51 er sproget karakteriseret af følgende typer af fejl: blødt $d$, fx ymyg, stumt $d$, fx got, lan, kand, dobbeltkonsonant, fx desvare, helle (for hele), r-fejl, han høre, og også fejl på grund af dialekt.

I vore dage undersøges skrivefærdigheden internationalt, $\mathrm{fx}$ med Pisa-undersøgelserne. Her skal eleverne finde informationer, fortolke sætningerne, reflektere over sagen, og vurdere teksten, og man fandt mange såkaldt funktionelle analfabeter, dvs. børn og voksne som måske godt kan læse, men som ikke kan anvende læsning eller skrivning funktionelt. Man fandt i andre undersøgelser at indvandrerbørn klarer sig dårligt, at piger klarer sig bedre end drenge, og at der i 1998 i Danmark var $46 \%$ med utilstrækkelig læsefærdighed mod $37 \%$ i Finland, $33 \%$ i Norge og $28 \%$ i Sverige. Undersøgelse af studentereksamensstile viser 
at antallet af orddelingsfejl, fx køle anlag, er femdoblet i 1990'erne.

Man kan her savne overvejelser over om man virkelig kan måle andet end antallet af formelle fejl. Kan man undersøge læsernes teksttolkning, refleksion og vurdering med de prøver som man bruger, og fungerer de på samme måde i forskellige kulturer? Resultatet af disse 'målinger' har jo store konsekvenser for skolepolitikken.

17.3 Breve og brevbøger (10 sider) er også skrevet af Vibeke Sandersen. Det korte afsnit nævner privatbreve , indbydelser, kondolencebreve og gækkebreve og handler især om bøger med mønsterbreve med betoning af titler og formularer som: Jeg skriver dig til for at lade dig vide. Vibeke Sandersen nævner at stilens ubehjælpsomme bredde og de mange høflighedsformler konkurrerer med den naturlige stil.

17.4. Danskfaget $i$ skolen (16 sider) er skrevet af Jens Raahauge som definerer skolens opgave som det "at undervise i sproget og anvende det som redskab i undervisningen" (side 321). I begyndelsen, skriver han, udstrakte læsefærdighederne sig (som nævnt i et tidligere afsnit) til fadervor, trosbekendelsen og de 10 bud. I 1814 blev der indført færdighedsindlæring i læsning, skrivning og også i mundtlig dansk med eksamen. Med højskolerne fik man prøvefri formidling gennem fortælling, og i 1903 indførtes almenskoler og en mellemskole hvor der blev lagt vægt på både "Aandsudvikling og Dannelse" (side 326), og en praktiske mellemskole som blev kaldt fri mellem.

Med Den blå betenkning betonedes så i 1958 respekten for det ikke målelige, og der kom gruppearbejde, ordbilledmetode, og tekstanalyse med et skema for tid, sted, handling, miljø og personer. Det beskrives hvorledes Mogens Jansen fik reduceret grammatikken til hvad der var nok til tegnsætning. Faghæftet Dansk 1984 betonede med beskrivelserne af at lytte, tale, læse og skrive både færdighed og dannelse. Siden er der kommet procesorienteret skriveundervisning og multimodalitet. I Falles mål fra 2009 indførtes læringsmålstyring for læsning, fremstilling, fortolkning og kommunikation med bl. a. nedtoning af fiktionsskrivning og afvikling af dannelsesdimensionen.

Af afsnittet fremgår det at modersmålsundervisningen i Danmark har drejet sig om både færdighed og dannelse, og at vægten er flyttet fra færdighed til dannelse, og så i 2010'erne tilbage igen til færdighed. Jens Raahauge slutter med at konstatere: "Det oprindelige færdigheds-, 
videns- og dannelsesfag er afløst af et kompetencefag. Dannelsesdiskursen er glidende blevet erstattet af en markedsdiskurs. Begreber som skønlitteratur, undervisning og dannelse optræder ikke i kompetencemålene" (side 336).

17.5 Normer og normering (28 sider) er skrevet af Henrik Galberg Jacobsen. Afsnittet handler om sprogrøgt, og (offensiv og defensiv) normering af det danske sprog. Det begyndte på området for ordforråd med Peder Syv og Henrich Gerner som foreslog at commandere erstattedes af befale, obligere af forpligte. Ørsted indførte ilt og brint for oxygen og hydrogen og Otto Jespersen skrev av i stedet for af. Sven Clausen kæmpede med sit Nordisk Sprogstræv for ord som kvald, red, skryde, bøde.

I 1955 oprettedes Dansk Sprognævn, som bl. a. organiserede en diskussion om de danske talord, men femogtres blev ikke til sekstifem, selv om det i en periode var almindeligt på kvitteringer og checks. 1978 oprettedes Nordisk Sprogsekretariat som forgæves advokerede for tegnrude i stedet for display. Sprognævnsformanden Davidsen-Nielsen gik ind for parallelsproglighed som modspil til sprogæderi, domænetab og amerikansk kulturimperialisme. Et nutidigt eksempel er fagfallebedømmelse i stedet for peer review. Som Henrik Galberg Jacobsen beskriver det, synes sprognormering kun at have haft små og tilfældige effekter på sprogets udvikling.

400 års retskrivningsnormering begynder med Jacob Madsen 1586 og senere Peder Syv der ville afskaffe de fremmede bogstaver $c, q, x$ og $z$, mens Gerner indførte store bogstaver i substantiverne, dobbeltbogstaver, stumme bogstaver, skel mellem $ø$ og $\ddot{o}$ og bolle- $a$. Rasmus Rask foreslog udtalen som grundlag for at afskaffe $c, q, x \operatorname{og} z$. I næste århundrede har Poul Henningsen kæmpet for blir og ha, og Hartvig Frisch afskaffede med sin Retskrivningsreform 1948 store bogstaver i substantiverne og datidsformerne kunde, skulde og vilde. I 1997 kom der for første gang en Retskrivningslov, og den store kommakrig omkring årtusindskiftet resulterede ikke i en kommateringsreform (men det blev afhandlet i bind 2 af Dansk Sproghistorie). Ud fra en standardsprogsideologi har nogen kæmpet for udbredelse af rigssproget, som (ifølge en billedtekst) var det som TV-avisoplæseren Henning Skaarup talte. Henrik Galberg Jacobsen fastslår, efter Inge Lise Pedersen, 
hvorledes standardsproget udvikler sig i tre faser: 1. selekteringen af talesprogsvarieteten, 2. kodificeringen i ordbøger og grammatikker, og 3. generaliseringen.

17.6 Dansk som andetsprog (13 sider) er skrevet af af Anne Holmen. Hun skriver at $14 \%$ af folkeskolens elever har dansk som andetsprog fordi deres forældre (i faldende antal) kommer fra: Polen, Syrien, Tyrkiet, Tyskland og andre lande. Dette er blevet betegnet som tosprogethed, som Anne Holmen definerer som det at have et andet modersmål (forstået som barnets første sprog) end dansk. Hun skelner mellem successiv eller simultan tosprogethed, mellem strukturel og funktionel tosprogethed, mellem individers flersprogethed og samfunds mangesprogethed, og mellem modersmål, andetsprog og fremmedsprog.

Andetsprogstaleres danskfærdigheder afhænger dels af deres modersmål, dels af grunden til at de skal bruge to sprog, og dels af om færdighederne undersøges strukturelt eller funktionelt. Karen Lund har fx fundet at for udtryk for begrebet flertal er det strukturelt set lettest at lære hele ord, $\mathrm{fx}$ to, mange, middelsvært at lære bøjningsendelser med mening: hus-e, loft-er, og sværest at lære bøjningsendelser med uigennemskuelig betydning: sød-e børn. Problemerne for børn med et andet modersmål kan funktionelt set også skyldes skolens genrer og upersonlige stil.

Modersmålsundervisningen i de danske skoler er et politisk sprængfarligt emne som folk har stærke holdninger til. Der er begrebsforvirring både i sagen og i afsnittet. Det der politisk korrekt kaldes tosprogethed, er måske blot en eufemisme for dobbelt halvsprogethed, og hvorfor nævnes det slet ikke at børn i Danmark der har et andet modersmål end dansk, kunne have fordel af, samtidig med at de lærer dansk som andetsprog, at lære at tale og skrive på deres eget modersmål - hvad massiv forskning i USA faktisk tyder på.

Kapitel 17 Dannelse og uddannelse handler om sprogpolitik, som ikke synes at have været så sproglig endda, og om sprogets institutioner, som ikke synes at have haft så stor virkning på sproget, men mere handler om holdninger til sproget og samfundet. 


\section{DANSK I BRUG}

Hele bindet Dansk i brug er inddelt i kapitlerne 14. Lov, bibel og salmer, 15. Viser, sange og ordsprog, 16. Sprog og medier og 17. Dannelse og uddannelse. Men mens kapitelinddelingen i bind 2 og 3 sker på grundlag af velkendte sprogteoretiske begreber som ordforråd, bøjning og syntaks, er dette bind om Sproget $i$ brug inddelt både efter genrer og efter samfundets sproginstitutioner ( $\mathrm{og}$ med det historiske forløb fra middelalder til i dag skitsemæssigt gentaget i de enkelte kapitler). Selv om der skal komme et kapitel om Stilidealer og stilforskydning i bind 6, kan man i dette bind savne et afsnit om begrebet 'sprogbrug', om hvordan forholdet er mellem samfund, institutioner og genrer på den ene side og sproglig stil, ordforråd, morfologi og syntaks på den anden side. Mens de sidste er bestemt af konstituerende grammatiske regler for det enkelte sprog, er sprogets brug bestemt af pragmatiske principper som historisk ændrer sig parallelt i hele Europa, og sproget i en genre eller tekstart er antagelig gennem historien blevet udformet til at passe til situationer i det enkelte samfunds institutioner - som en nøgle i en lås - de er blevet til samtidigt.

Sådanne sammenhænge påvises nogle steder i dette bind, $\mathrm{fx}$ bedst $\mathrm{i}$ 16. Sprog og medier, men man mangler en overordnet teori om hvordan det skal beskrives. Det vises hvordan sprogbrugen er en virkning af ændringer i de materielle forhold, fx sproget i radio og tv, og andre steder af magten i samfundet, fx i lovtekster og bibeltekster, og endelig også af de fremvoksende institutioner, fx salmesprog og højskolesangen. Men det kunne også være interessant at vide hvordan sproglig stil sætter sine spor i genrerne, i institutionerne, i samfundet og i historien, kort sagt: hvordan påvirker sproget samfundet? Dansk i brug er vel også det der er emne for sociolingvistikken, som imidlertid ikke nævnes eller berøres?

Man kan også undre sig over hvilke genrer der er blevet taget ud til at få et af de 16 afsnit, fx lov, bibel, salmer, højskolesangen og lejlighedsdigte. Hvorfor lige dem? Hvorfor ikke prædikener, historieskrivning, ridderromaner, og skuespil? Er det bare efter de forhåndenværende søms princip (af hvad der allerede findes beskrivelser af) eller ligger der en tanke bag? 
Skønt bind 4 Dansk Sproghistorie med undertitlen Dansk i brug alt i alt er ufokuseret og uden teoretisk sammenhæng i studiet af de lidt tilfældigt valgte eksempler på dansk sprogbrug, er det samtidig så stofmættet og rigt på veldokumenterede eksempler at man bliver klogere på de mange anvendelser af dansk sprog i historiens forløb. Mange genrespecifikke historiske udviklinger skitseres fint, især for sprog og medier. 